\title{
KERAGAMAN ARTHROPODA PADA PADI SAWAH DENGAN PENGELOLAAN TANAMAN TERPADU
}

\author{
I Nyoman Widiarta ${ }^{1}$, Dede Kusdiaman ${ }^{1}$, dan Suprihanto ${ }^{1}$
}

\begin{abstract}
Arthropods diversity in rice field with integrated crop management. Integrated crop management (ICM) has been introduced to improve rice intensification system in Indonesia. Organic matter has been recommended to be added into the rice fields to improve soil fertility. In order to minimize hazard of pesticide integrated pest management (IPM) is incorporated into ICM to control pest. The objectives of this research were to study arthropod diversity in rice field where organic matter was added and pesticide was used rationally. The research was conducted at experimental fields of Indonesian Center for Rice Research in Sukamandi, during the wet season of 2005/2006. Diversity of arthropod was observed in ICM, organically-farm field, and farmer technique paddy fields. Arthropod was sampled using a FARMCOP suction apparatus. Results of this study indicated that in ICM paddy fields were harbored by more insect, predators and parasitoids especially during early growing stage of rice plants. Thus adding organic matter and rationaly use of insecticide could increase the natural enemies for insect pests in the field.
\end{abstract}

Key words : arthropod, diversity, ICM, rice paddy

\section{PENDAHULUAN}

Dari sudut pandang usahatani padi, serangga secara umum dikelompokkan menjadi serangga hama, serangga berguna, dan serangga netral. Sebagai organisme berguna, serangga ada yang berperan sebagai musuh alami baik sebagai parasitoid maupun predator, serangga penyerbuk, dan dekomposer. Sedangkan serangga netral kerap menjadi mangsa predator, sehingga peranannya sangat besar dalam menjaga keseimbangan ekosistem padi sawah. Namun demikian, kebanyakan petani memandang serangga sebagai organisme perusak sehingga harus dikendalikan. Pada kenyataannya keragaman jenis serangga mempunyai peran yang sangat penting dalam ekosistem padi sawah (Siswanto \& Wiratmo, 2001; Soelaksono, 2001). Keanekaragaman hayati serangga berpengaruh terhadap kuantitas dan kualitas produk yang dihasilkan. Pada ekosistem alami, umumnya telah terjadi kestabilan populasi hama dan musuh alaminya sehingga keberadaan serangga hama pada pertanaman tidak lagi merugikan. Kenyataan tersebut perlu dikembangkan sehingga mampu menekan penggunaan pestisida untuk mengendalikan serangan hama di lapangan, terutama pada tanamantanaman yang berorientasi ekspor dan mempunyai nilai ekonomis tinggi.

Ekosistem padi sawah bersifat cepat berubah karena sering terjadi perubahan akibat aktivitas pengolahan tanah, panen, dan bera. Bera antar waktu tanam tidak hanya menekan populasi hama tetapi juga berpengaruh pada kerapatan populasi musuh alami pada awal musim tanam berikutnya, sehingga pertumbuhan populasi predator tertinggal (Widiarta, et al., 2000). Rendahnya kepadatan populasi musuh alami pada saat bera karena mangsa (termasuk hama) juga rendah. Pada saat tersebut apabila serangga netral cukup tersedia akan berpengaruh baik terhadap perkembangan musuh alami. Peningkatan kelimpahan serangga netral akan meningkatkan pengendalian alami melalui peningkatan aktivitas pada jaring-jaring makan (Winasa, 2001).

Pelajaran yang dapat diambil dari penerapan sistem intensifikasi padi sawah dari sejak Bimas sampai dengan Supra-Insus salah satunya adalah kondisi tanah menjadi "sakit" karena kekurangan kandungan bahan organik tanah. Untuk memperbaikinya diintroduksikan pendekatan budidaya pengelolaan tanaman terpadu (PTT) yang salah satu anjurannya adalah menggunakan bahan organik untuk memperbaiki kondisi tanah, bukan sebagai sumber unsur makro yang diperlukan tanaman. Penambahan bahan organik yang dilakukan sebelum musim panas di China dilaporkan meningkatkan keragaman serangga terutama serangga-serangga netral (Cheng, 1995). Dengan demikian penerapan PTT diperkirakan berdampak positif pada keragaman arthropoda pada padi sawah.

Pemberian bahan organik kedalam tanah akan memperbaiki sifat-sifat tanah (fisik, kimia dan biologi 
tanah) dan akan menstimulasi aktivitas flora dan fauna tanah. Dalam biologi tanah pemberian kompos dapat meningkatkan populasi jasad renik dalam tanah karena kompos jerami tersebut digunakan sebagai sumber energi sehingga proses dekomposisi bahanbahan organik di dalam tanah semakin meningkat. Ponnamperuma (1984) menyatakan bahwa $80 \%$ hara nitrogen yang terserap tanaman padi pada tanah subur berasal dari mineralisasi bahan organik tanah.

Pengendalian hama terpadu menjadi bagian teritegrasi dalam PTT (Makarim \& Las, 2005) karena pengendalian hama dan penyakit adalah tujuan antara budidaya tanaman. PHT memperbesar peran pengendalian alami dan penggunaan pestisida secara rasional berdasarkan hasil pengamatan.

Pada tulisan ini diuraikan hasil pengamatan diversitas arthropoda pada pendekatan PTT dibandingkan dengan pendekatan budidaya padi organik dan konvensioanal petani.

\section{METODE PENELITIAN}

Tempat dan Waktu Penelitian. Penelitian dilakukan di Kebun Inlitpa Sukamandi, Balai Besar Penelitian Tanaman Padi (BB-Padi), pada musim hujan (MH) 2005/2006.

Budidaya. Luasan petak pengamatan dari setiap cara budidaya adalah 0,15 ha. Pada tiap cara budidaya dilakukan sampling masing-masing pada masa bera, pesemaian, stadia vegetatif, anakan maksimum, dan generatif awal. Padi varietas Ciherang ditanam pada umur 15 hari setelah sebar, dengan jarak tanam $25 \mathrm{~cm}$ x $25 \mathrm{~cm}$. Ketiga cara budidaya dibedakan dalam pemberian bahan organik dalam pengelolaan tanaman padi, antara lain:

1. Budidaya konvensional (petani). Cara budidaya konvensional adalah cara umum yang dilakukan petani padi sawah, diantaranya tanpa menggunakan pupuk kandang, penggunaan pupuk an-organik dan pemakaian insektisida yang intensif. Pupuk yang diberikan per-ha adalah 400 $\mathrm{kg}$ urea, $100 \mathrm{~kg} \mathrm{SP36,} 100 \mathrm{~kg} \mathrm{KCl}$. Pada saat persemaian dilakukan aplikasi insektisida Spontan dan Furadan serta herbisida Indamin masingmasing sekali. Pada saat petanaman insektisida diaplikasikan 8 kali masing-masing 3 kali Furadan, 3 kali Spontan dan 2 kali Chick. Dosis yang digunakan pada setiap kali aplikasi adalah untuk Furadan 40 kg/ha, Spontan 2cc/l dan Chick
$3 \mathrm{cc} / \mathrm{l}$, sedangkan untuk Indamin dosisnya adalah $2 \mathrm{cc} / \mathrm{l}$. Insektisida/herbisida cair diaplikasikan menggunakan sprayer dengan volume semprot 500 1/ha.

2. Budidaya padi dengan pengelolaan tanaman terpadu (PTT). Cara budidaya pengelolaan tanaman terpadu (PTT) adalah pengelolaan tanaman padi sawah secara sinergis antar komponen teknologi seperti penggunaan benih bermutu dari varietas unggul baru, penggunaan bahan organik, pengairan berselang-seling, dan pemakaian pupuk an-organik yang seimbang sesuai kandungan hara dan kebutuhan tanaman. Penggunaan pestisida dilakukan secara rasional dengan menerapkan pengendalian hama terpadu. Pupuk kandang yang diaplikasikan sebanyak 2 t/ha, sedangkan pupuk an-organiknya per-ha adalah $300 \mathrm{~kg}$ urea, $100 \mathrm{~kg} \mathrm{SP36,} 100 \mathrm{~kg} \mathrm{KCl}$. Pada saat persemaian dilakukan aplikasi insektisida Spontan dan Furadan serta herbisida Indamin masing-masing sekali. Pada pertanaman diaplikasikan Furadan 2 kali dan Chick 1 kali. Dosis yang digunakan pada setiap kali aplikasi adalah untuk Furadan $40 \mathrm{~kg} / \mathrm{ha}$, Spontan $2 \mathrm{cc} / \mathrm{l}$ dan Chick $3 \mathrm{cc} / \mathrm{l}$, sedangkan untuk Indamin dosisnya adalah 2 cc/l. Insektisida/herbisida cair diaplikasikan menggunakan sprayer dengan volume semprot $500 \mathrm{l} / \mathrm{ha}$.

3. Budidaya padi organik (organik). Cara budidaya tanaman organik adalah pengelolaan tanaman padi menggunakan bahan organik sebagai sumber hara tanpa menggunakan pupuk an-organik. Pupuk kandang yang diaplikasikan sebanyak 2 t/ha. Pestisida tidak digunakan sama sekali.

Metode Sampling. Studi dilakukan dengan metode eksplorasi sebagaimana umumnya dilakukan pada studi ekologi komunitas seperti yang dilakukan oleh Heong, et al. (1990) untuk mengetahui keragaman arthropoda. Pengamatan dimulai dari saat tanaman umur dua minggu setelah tanam sampai fase vegetatif akhir, dan masa bera. Keragaman arthropoda diamati pada lahan sawah dengan tiga cara budidaya tanaman padi. Keragaman arthropoda diambil dari satu unit sampel seluas $1 \mathrm{~m}^{2}$ terdiri dari 16 rumpun tanaman. Penentuan unit sampel pada masing-masing cara budidaya dilakukan secara acak, dengan jumlah 15 unit sampel untuk masing-masing cara budidaya. Pengamatan dilakukan 2 minggu sekali dengan alat penghisap serangga FARMCOP (Carino et al., 1979). Semua arthropoda yang terhisap disimpan dalam 
Tabel 1. Kelompok arthropoda pada beberapa cara budidaya tanaman padi, di Sukamandi,pada MH 2005/2006

\begin{tabular}{lll}
\hline Kelompok & & Ordo/spesies \\
\hline Serangga Hama & Nilaparvata lugens Stall. & Cnaphalocrocis medinalis \\
& Sogatella furcifera & Scotinophara lurida Brum \\
& Nephotettix virescens & Orthoptera-1 \\
& Recilia dorsalis & \\
\hline Predator & Cyrtorhinus sp. & Oxyopes sp. \\
& Paederus perigrinus & Tetragnatha sp. \\
& Coccinela sp. & Lycosa sp. \\
& Ophionea nigrofasciata & Araneae-1 \\
\hline Parasitoid & Telenomus sp. & \\
& Trichogramma sp. & \\
& Opius sp. & Hymenoptera-4 \\
& Diptera-1 & Hemiptera-1 \\
Culex sp. & Hemiptera-2 \\
& Hymenoptera-1 & Hymenoptera-5 \\
& Hymenoptera-2 & Coleoptera-1 \\
\hline
\end{tabular}

tabung koleksi serangga dengan alkohol $70 \%$, untuk kemudian diidentifikasi, dihitung jenis dan jumlahnya di laboratorium. Arthropoda dikelompokkan menjadi kelompok hama, musuh alami (predator, parasitoid), dan serangga netral.

Analisis Data. Struktur komunitas arthropoda dianalisis dengan menghitung indeks keanekaragaman, kemerataan, dan dominasi spesies. Keanekaragaman dihitung dengan indek Shannon $\left(\mathrm{H}^{\prime}=-\Sigma(\mathrm{ni} / \mathrm{N}) \ln (\mathrm{ni} / \mathrm{N})\right)$ dan indeks kemerataan (E =H'/In (S)) (Ludwig \& Reynold, 1988). Proporsi spesies yang paling dominan diukur dengan indek Berger-Parker (d= Nmax/N) (Southwood, 1986).

\section{HASIL DAN PEMBAHASAN}

Hasil pengamatan menunjukkan bahwa komunitas arthropoda dapat dikelompokkan ke dalam arthropoda hama, predator, parasitoid dan netral (Tabel 1).

Meskipun ditemukan ada 8 spesies serangga yang berperan sebagai hama, tetapi juga ditemukan musuh alami yang terdiri dari sekitar 8 spesies berperan sebagai predator dan 3 spesies sebagai parasitoid. Selain itu juga ditemukan serangga netral (10 spesies) yang tentunya juga berperan dalam komunitas arthropoda. Secara keseluruhan jumlah spesies arthropoda yang dijumpai lebih rendah dibandingkan dengan keragaman arthropoda di Ciranjang, Cianjur pada tahun 1997/1998 (Herlinda et al., 2000), tetapi tidak jauh berbeda dengan jumlah spesies arthropoda di Pusakanagara pada tahun 1999/2000 (Trisnaningsih et al., 2000). Hal tersebut menunjukkan keragaman arthropoda di dataran rendah pantai utara (pantura) lebih rendah dari di dataran tinggi di Jawa Barat.

Kerapatan Populasi Arthropoda. Dilihat dari kerapatan populasi arthropoda yang ditemukan pada masing-masing cara budidaya tanaman padi (Gambar 1) menunjukkan bahwa pada umur 2 minggu setelah tanam (2 MST) kerapatan populasi serangga hama tidak berbeda nyata antara ketiga cara budidaya. Ketiga cara budidaya menunjukkan kerapatan populasi yang rendah. Lain halnya dengan kerapatan populasi musuh alami dan serangga netral, pada cara budidaya PTT mempunyai kerapatan yang lebih tinggi dibandingkan cara budidaya yang lain dan secara statistik menunjukkan perbedaan yang nyata.

Pada umur tanaman 4 MST, serangga hama, serangga netral dan musuh alami pada cara budidaya PTT secara nyata menunjukkan kerapatan lebih tinggi dibandingkan cara budidaya organik dan petani. Hal ini bertahan sampai pada 6 MST. Kerapatan populasi serangga hama pada budidaya PTT meningkat tajam pada 8 MST dan secara nyata berbeda dibandingkan cara budidaya organik dan petani. Tetapi peningkatan kerapatan populasi serangga hama juga diikuti peningkatan populasi musuh alami yang juga 

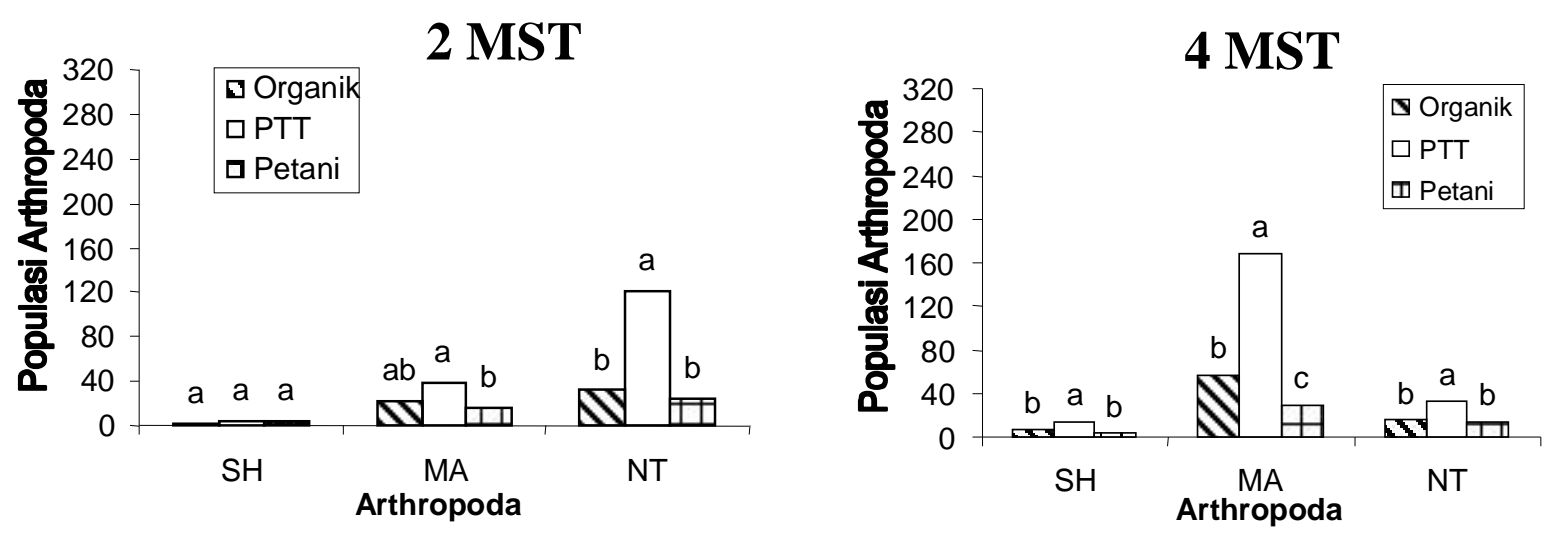

\section{MST}
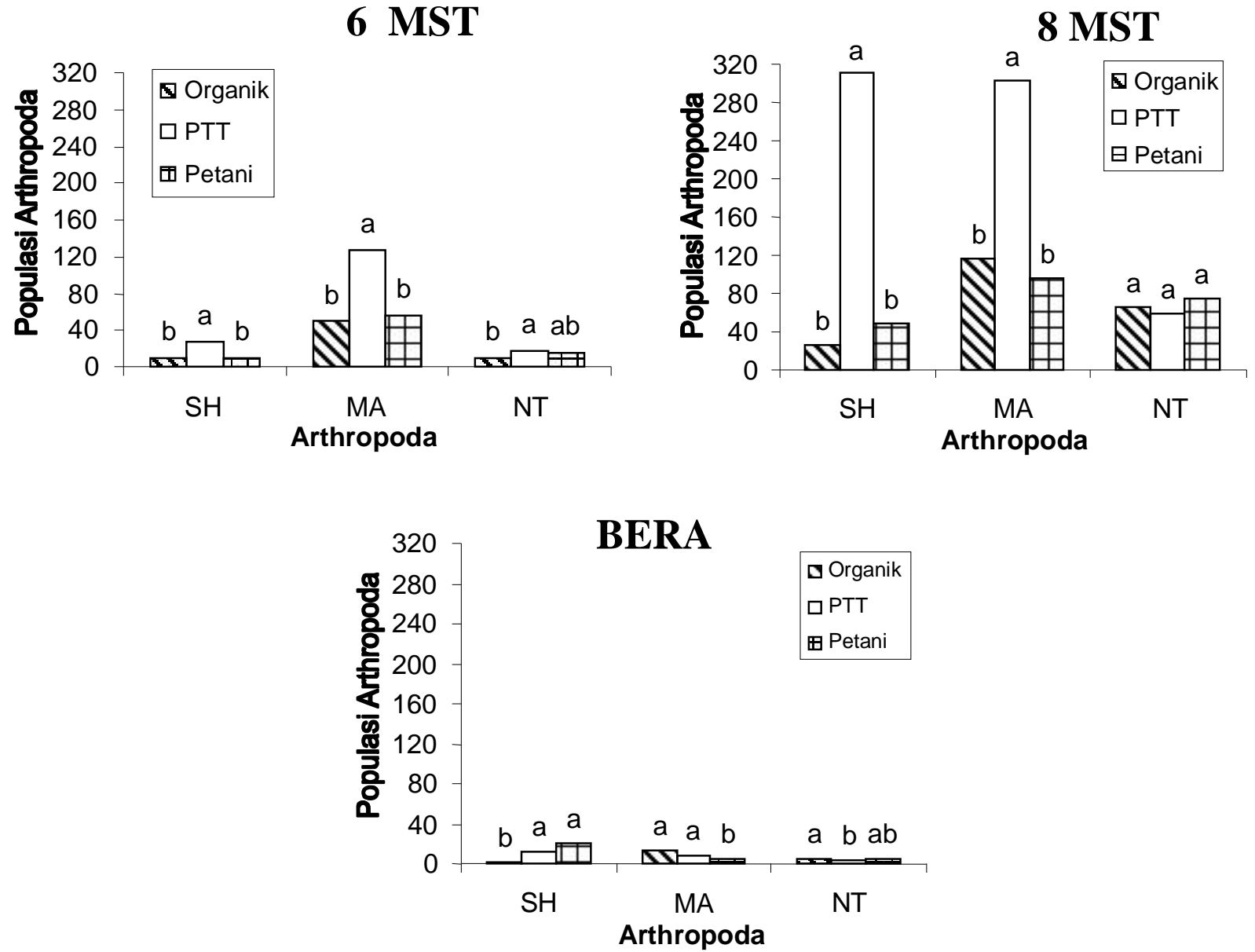

Gambar 1. Kerapatan populasi arthropoda di tiga cara budidaya tanaman padi pada umur 2, 4, 6, dan 8 MST, serta pada masa bera. $(\mathrm{SH}=$ serangga hama, $\mathrm{MA}=$ musuh alami, $\mathrm{NT}=$ serangga netral). 
meningkat secara tajam dibanding pada kedua cara budidaya yang lain.

Secara umum pada vegetatif awal maupun vegetatif akhir dapat dikatakan populasi arthropoda terutama musuh alami pada PTT selalu tinggi. Tingginya populasi arthropoda pada cara budidaya PTT dibandingkan dengan organik dan petani diduga berkaitan dengan input teknologi yang digunakan. Pada cara petani penggunaan insektisida akan menekan populasi serangga hama dan juga musuh alaminya seperti kondisi pada saat 8 MST, sedangkan pada PTT tingginya serangga hama diimbangi oleh musuh alami. Pada cara budidaya organik mutlak tanpa menggunakan bahan kimia termasuk pupuk kimia, kerapatan populasi wereng coklat, wereng hijau maupun wereng punggung putih rendah karena perkembangan arthropoda kurang baik pada habitat tersebut (Kajimura et al., 1993).

Pada masa bera, kerapatan populasi arthropoda baik serangga hama, musuh alami, maupun serangga netral menurun. Pada masa bera ini kerapatan serangga hama tertinggi pada cara budidaya petani yaitu 20 ekor per unit sampel, tetapi tidak berbeda nyata dengan PTT (11,2 ekor/unit sampel). Tetapi sebaliknya untuk kerapatan populasi musuh alami dan serangga netral, tertinggi pada cara budidaya organik, diikuti oleh cara PTT, dan terendah pada cara budidaya petani.

Komposisi Arthropoda. Dilihat dari proporsi arthropoda yang ditemukan pada masing-masing cara budidaya tanaman padi, menunjukkan bahwa pada umur 2 MST, serangga netral dan musuh alami lebih banyak dibandingkan serangga hama pada ketiga cara budidaya (Gambar 2). Proporsi serangga netral pada ketiga cara budidaya bahkan lebih mendominasi. Pada cara budidaya PTT, lebih dari $70 \%$ populasinya adalah serangga netral terutama pada awal stadia pertumbuhan tanaman. Hal ini tidak bertahan sampai pada pada 4 MST, dimana proporsi serangga netral digeser oleh proporsi musuh alami pada ketiga cara budidaya. Pada umur 6 MST proporsi musuh alami masih tetap tinggi pada ke tiga cara budidaya tersebut. Pada 8 MST proporsi populasi serangga hama meningkat terjadi pada cara budidaya PTT dan petani, tetapi proporsi serangga hama ini masih sebanding dengan proporsi musuh alaminya.

Pada saat bera, proporsi serangga hama pada cara budidaya petani meningkat tajam hingga mencapai $70 \%$ dari arthropoda yang ditemukan. Pada masa bera ini, proporsi musuh alami dan serangga netral pada cara budidaya organik tetap tinggi. Pada PTT proporsi musuh alami juga relatif masih tinggi, meskipun di bawah proporsi serangga hama yang mencapai hampir 50\%. Hal ini menunjukkan bahwa cara budidaya organik mampu menekan proporsi serangga hama dan mempertahankan proporsi musuh alami dan serangga netral tetap tinggi dari fase vegetatif awal sampai pada masa bera. Demikian juga pada cara budidaya PTT, mampu menekan proporsi serangga hama, dan mempertahankan proporsi musuh alami, meskipun tidak sebaik pada cara budidaya organik. Apabila keadaan ini dapat dipertahankan, maka akan mengurangi sumber hama bagi pertanaman selanjutnya.

Tingginya kerapatan populasi dan proporsi musuh alami pada cara budidaya PTT dan organik yang dijumpai pada penelitian ini kemungkinan terjadinya seperti yang dilaporkan oleh Cheng (1995) di Cina. Pada budidaya PTT dan organik bahan organik ditambahkan ke lahan seperti halnya yang dilakukan sebelum musim tanam padi di Cina. Pemberian bahan organik meningkatkan proporsi serangga netral pada awal pertumbuhan tanaman (2MST) yang merupakan sumber makanan bagi musuh alami terutama predator.

Keanekaragaman, Dominasi, dan Kemerataan Spesies. Pada fase vegetatif awal, indek keragaman pada cara budidaya petani adalah yang tertinggi, sedangkan terendah pada cara budidaya PTT. Pada fase vegetatif akhir, indeks keanekaragaman pada cara budidaya petani mengalami penurunan, sedangkan pada cara organik meningkat menjadi yang tertinggi (Tabel 2). Bahkan sampai pada masa bera, yaitu setelah tanaman padi tidak ada. Pada saat bera indek keragaman pada cara budidaya PTT menyamai indek keragaman budidaya organik. Faktor yang mendukung tingginya indek keanekaragaman spesies pada cara budidaya organik kemungkinan adalah tidak digunakannya insektisida kimia pada cara budidaya ini. Menurut Tulung et al. (2000), cara pengelolaan misalnya dengan penggunaan pestisida turut berpengaruh dalam menurunkan keanekaragaman spesies. Hal yang sama juga dilaporkan oleh Arifin et al. (1997). Pada cara budidaya organik tidak digunakan pestisida kimia maupun bahan kimia lainnya, jadi mutlak hanya digunakan bahan organik, sehingga memungkinkan tingginya keanekaragaman spesies. Demikian pula pada cara budidaya PTT yang 

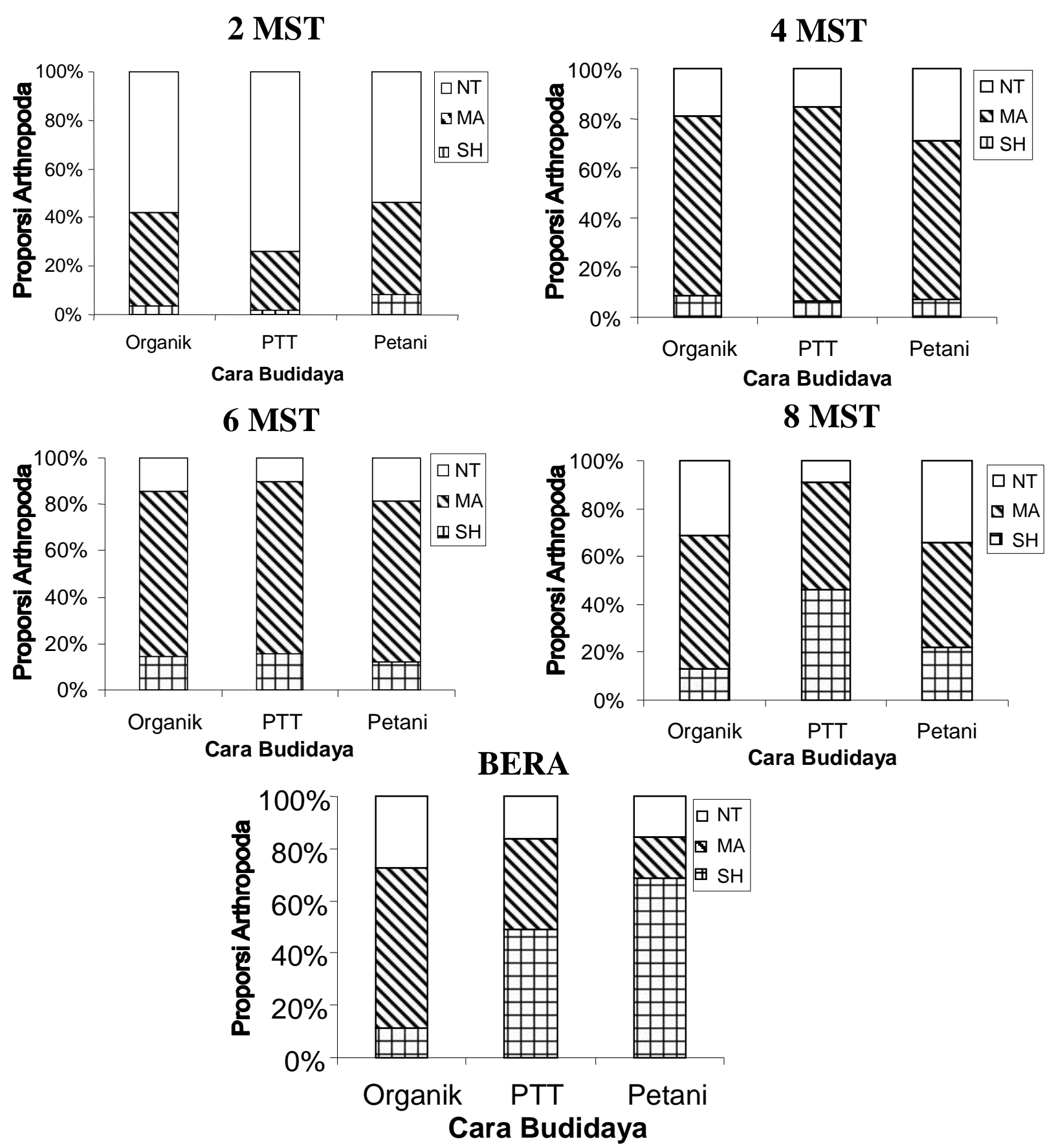

Gambar 2. Proporsi arthropoda di tiga cara budidaya tanaman padi pada umur 2 MST, 4 MST, 6 MST, 8 MST, dan bera. 
Tabel 2. Indek keanekaragaman arthropoda pada tanaman padi dengan tiga cara budidaya, di Sukamandi MH 2005/2006

\begin{tabular}{|c|c|c|c|c|c|c|c|c|c|}
\hline \multirow{2}{*}{$\begin{array}{l}\text { Cara } \\
\text { Budidaya }\end{array}$} & \multicolumn{3}{|c|}{ Keanekaragaman } & \multicolumn{3}{|c|}{ Dominasi } & \multicolumn{3}{|c|}{ Kemerataan } \\
\hline & VAW & VAK & Bera & VAW & VAK & Bera & VAW & VAK & Bera \\
\hline Organik & 2,267 & 2,416 & 2,230 & 0,329 & 0,364 & 0,247 & 0,704 & 0,751 & 0,845 \\
\hline PTT & 1,944 & 1,628 & 2,230 & 0,439 & 0,442 & 0,282 & 0,597 & 0,512 & 0,813 \\
\hline Petani & 2,531 & 2,255 & 1,717 & 0,231 & 0,377 & 0,560 & 0,777 & 0,719 & 0,619 \\
\hline
\end{tabular}

VAW: vegetatif awal; VAK: vegetatif akhir.

menggunakan insektisida secara rasional hanya bila diperlukan, sehingga indek keanekaragaman spesies relatif stabil dan bahkan meningkat pada masa bera menyamai cara budidaya organik. Sebaliknya pada cara budidaya petani, dimana penggunaan bahan kimia yang intensif (pupuk dan pestisida), meskipun pada fase vegetatif awal tanaman mempunyai keragaman paling tinggi, tetapi kemudian terjadi penurunan keragamannya sampai pada masa bera menjadi yang terendah.

Tingkat dominasi arthropoda tertinggi pada cara budidaya PTT pada vegetatif awal maupun akhir. Pada budidaya PTT ini terdapat satu spesies predator yang kerapatan populasinya jauh lebih tinggi dibanding spesies lainnya, yaitu Paederus sp. Tingkat dominasi pada cara budidaya petani cenderung meningkat dari vegetatif awal, vegetatif akhir sampai masa bera. Hal ini juga terlihat pada tingkat kemerataan, dimana pada budidaya PTT fase vegetatif awal maupun vegetatif akhir mempunyai tingkat kemerataan yang rendah karena adanya dominasi oleh spesies tertentu saja.

Secara umum dilihat dari indek keanekaragaman arthropoda pada cara budidaya organik maupun PTT belum terlihat lebih baik dari cara budidaya petani (Tabel 2), kemungkinan karena waktu penerapannya yang belum terlalu lama. Akan tetapi apabila dilihat dari proporsi arthropoda terutama pada awal pertumbuhan tanaman saat tanaman umur 2 MST, proporsi serangga netral lebih tinggi pada cara budidaya organik dan PTT. Kondisi tersebut menguntungkan untuk perkembangan musuh alami, sehingga pada petakan dengan kedua cara budidaya tersebut perkembangannya lebih baik dilihat dari proporsinya pada 4-8 MST (Gambar 3).

Rantai Makanan. Arthropoda yang ditemukan dalam tiga cara budidaya tanaman tidak jauh berbeda jumlah spesiesnya (Gambar 3). Hanya proporsi dan populasinya yang berbeda. Pada Gambar 3 ditunjukkan bahwa tanaman padi adalah produsen utama, jumlah spesies yang berperan sebagai konsumen tingkat I (herbivora yang terdiri dari serangga hama dan netral) dalam rantai makanan terendah adalah pada cara budidaya petani, dimana hanya ditemukan 16 spesies, sedangkan pada PTT dan organik ditemukan 17 spesies. Satu spesies yang tidak ditemukan pada budidaya petani adalah satu spesies serangga netral. Dalam kelompok konsumen tingkat II (predator dan parasitoid) ditemukan jumlah spesies yang sama pada ketiga cara budidaya. Jumlah konsumen tingkat I dan tingkat II yang ditemukan pada penelitian ini lebih banyak dibandingkan dengan spesies di lahan sawah di daerah sub-tropik di Jepang (Hidaka, 1989), dengan demikian dapat diperkirakan rantai makanan di daerah tropik di Indonesia lebih komplek dari daerah sub-tropik di Jepang.

Dari penelitian ini diketahui bahwa pemberian bahan organik meningkatkan keberadaan serangga netral terutama pada awal pertumbuhan tanaman, sehingga musuh alami terutama predator mendapatkan sumber makanan pada saat arthropoda yang berpotensi sebagai hama belum berkembang. Untuk mencapai kondisi lingkungan yang dapat mengkonservasi musuh alami tidak perlu merubah budidaya tanaman sampai menjadi pertanian organik absolut, yang tidak mentolelir pemakaian input anorganik baik pupuk maupun pestisida. Pengurangan pemberian hara nitrogen akan menurunkan hasil panen, seperti pada percobaan ini hasil panen organik mencapai 4,2 t/ha gabah kering giling (GKG), sedangkan untuk PTT hasil panennya 5,1 t/ha GKG. Dengan demikian untuk meningkatkan peran pengendalian hayati (aktifitas predator) cukup dengan pemberian bahan organik seperti pada pendekatan PTT dan penggunaan pestisida rasional dengan pendekatan PHT. Dengan pendekatan PTT konservasi musuh alami dan produktivitas tinggi dapat dicapai. 


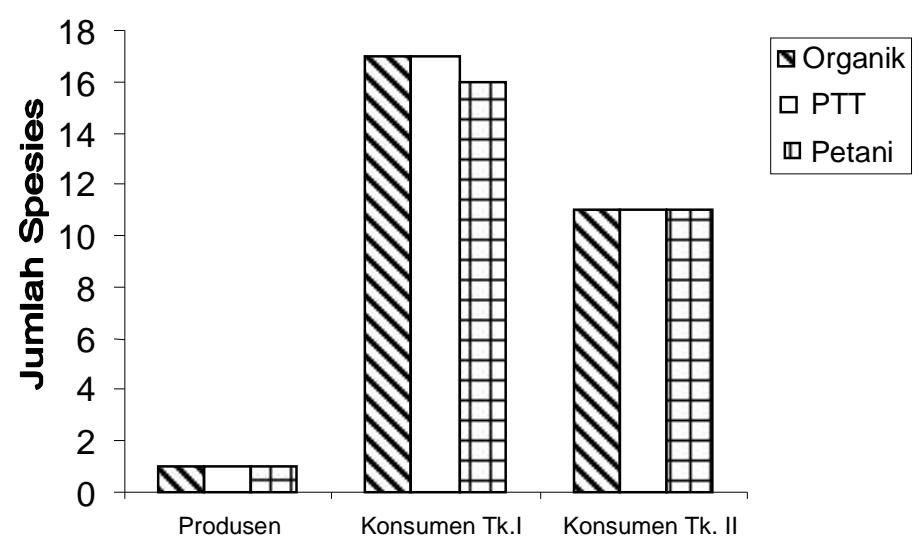

Gambar 3. Jumlah spesies dalam rantai makanan di tiga cara budidaya tanaman padi, Sukamandi MH 2005/2006.

\section{SIMPULAN DAN SARAN}

Simpulan. Pada cara budidaya PTT merupakan habitat yang paling baik bagi musuh alami (predator dan parasitoid). Pada cara budidaya PTT, kepadatan populasi dan proporsi musuh alami relatif tinggi terutama pada awal fase pertumbuhan tanaman padi dibandingkan dengan cara budidaya organik maupun petani. Cara budidaya organik juga merupakan habitat yang baik bagi musuh alami, meskipun kelimpahan populasinya lebih rendah dari PTT.

Cara budidaya dengan penggunaan bahan kimia secara rasional dapat meningkatkan kelimpahan musuh alami terutama predator. Sebaliknya, penggunaan bahan kimia (pupuk dan pestisida) yang intensif dalam budidaya tanaman dapat menekan populasi musuh alami.

Saran. Cara budidaya semi organik dengan penggunaan bahan kimia (pupuk dan pestisida) secara rasional dan memanfaatkan bahan organik sebagai input seperti PTT, dapat digunakan untuk meningkatkan regulasi alami bagi serangga hama dengan konservasi tanpa menurunkan produktivitas tanaman.

\section{DAFTAR PUSTAKA}

Arifin, M., I.B.G. Suryawan, BH. Priyanto \& A. Alwi. 1997. Diversitas arthropoda pada berbagai teknis budidaya padi di Pemalang Jawa Tengah. Penelitian Pertanian Tanaman Pangan 15: 5-12.
Carino, F.O., P. E. Kenmore \& V. A. Dyck. 1979. The FARMCOP suction sampler for hopper and predator in flooded rice fields. IRRN 4:2122.

Cheng, J. 1995. Arthropod community structures in rice ecosystem of China. Workshop on Suistainable Insect Pest Management in Tropical Rice. Bogor, Indonesia, 5-7 December 1995.

Herlinda, S., D.S. Kondowangko, I.W. Winasa \& A. Rauf. 2000. Fauna arthropoda penghuni habitat pinggiran di ekosistem persawahan. Hlm. 163-174 dalam: E. Sunaryo ed. Prosiding Simposium Keanekaragaman Hayati Artropoda pada Sistem Produksi Pertanian Perhimpunan Entomologi Indonesia 16-18 Oktober 2000. Cipayung.

Heong, K.L., G. Aquino \& A.T. Barrion. 1990. Comparing arthropod diversity in rice ecosystems. IRRN 15(6): 27-28.

Hidaka, K.1989. Organic Farming and Pest. 293p . in Nakasuji ed. Saturday Seminar Special Publication. Touzansha.

Kajimura, T., Y. Maeoka, I.N. Widiarta, T. Sudo, K. Hidaka \& F. Nakasuji. 1993. Effect of organic farming of rice plants on population density of leafhopper and plathopper. 
I. Population density and reprouctive rate. Jpn. J. Appl. Entomol. Zool. 37: 137-144.

Ludwig, J.A. \& J.F. Reynolds. 1988. Statistical Ecology. A Primer on methods and Compling. John Wiley and Sons, New York.

Makarim, A.K. \& Las I. 2005. Terobosan peningkatan produktivitas padi sawah irigasi melalui pengembangan model pengelolaan dan sumber daya terpadu (PTT). Hlm.115-127. dalam Suprihatno eds. Inovasi Teknologi Padi: Menuju Swasembada Beras Berkelanjutan. Pusat Penelitian dan Pengembangan Tanaman Pangan.

Ponnamperoma, F.N. 1984. Straw as a source of nutrients for wetland rice. In Organic matter and Rice. IRRI, Los Banos, Philippines.

Siswanto \& Wiratmo. 2001. Biodiversitas serangga pada pertanaman panili (Vanilla planifolia) dengan tanaman penutup tanah Arachis pintoi K. Prosiding Seminar Nasional Perhimpunan Entomologi Indonesia 6 Nopember 2001. Hlm 209-215.

Southwood, T.R.E. 1986. Ecologycal methods: With particular reference to the study of insect populations. Chapman and Hall, New York.

Soelaksono, S. 2001. Bekal pengetahuan dasar melaksanakan pengelolaan serangga bijaksana. Prosiding Seminar Nasional Perhimpunan Entomologi Indonesia 6 Nopember 2001. Hlm 1-6.
Trisnaningsih, Yoyo, \& J. Soejitno. 2000. Keanekaragaman hayati arthropoda pada berbagai system tanam padi. Hlm. 221-228 dalam: E. Sunaryo ed. Prosiding Simposium Keanekaragaman Hayati Artropoda pada Sistem Produksi Pertanian Perhimpunan Entomologi Indonesia 16-18 Oktober 2000. Cipayung.

Tulung, M., A. Rauf \& S. Sosromarsono. 2000. Keanekaragaman spesies laba-laba di ekosistem pertanaman padi. Hlm. 193-201 dalam: E. Sunaryo ed. Prosiding Simposium Keanekaragaman Hayati Arthropoda pada Sistem Produksi Pertanian Perhimpunan Entomologi Indonesia 16-18 Oktober 2000. Cipayung.

Widiarta, I.N., T. Suryana, \& D. Kusdiaman. 2000. Jenis anggota komunitas pada berbagai habitat lahan sawah bera dan usaha konservasi musuh alami pada padi tanaman serempak. Hlm. 185-182 dalam: E. Sunaryo ed. Prosiding Simposium Keanekaragaman Hayati Arthropoda pada Sistem Produksi Pertanian Perhimpunan Entomologi Indonesia 16-18 Oktober 2000. Cipayung.

Winasa, I.W., 2001. Arthropoda predator penghuni permukaan tanah di pertanaman kedelai: kelimpahan, pemangsaan, dan pengaruh praktek budidaya tanaman. Disertasi. Program Pascasarjana, IPB. 